\title{
CALVEZELLA, A NEW REPLACEMENT NAME FOR ARAGONELLA CALVEZ, 1989 (TYPE-SPECIES A. MARGINATA), A FORGOTTEN ORBITOLINID FROM THE ALBIAN OF SPAIN
}

\author{
Felix Schlagintweit
}

Received: 17 October 2019 / Accepted: 31 October 2019 / Published online: 2 November 2019

\begin{abstract}
Calvez (1989) described a new orbitolinid as Aragonella marginata n. gen., n. sp. from the Albian of Spain. The genus name however is a junior homonym of Hantkenina (Aragonella) Thalmann, 1942, an Eocene foraminiferal genus. In accordance with Article 60.3 of the International Code of Zoological Nomenclature (ICZN), the new replacement name Calvezella is introduced for Aragonella Calvez, 1989. This taxonomic revision leads to the new combination Calvezella aragonata (Calvez, 1987) for its only species.
\end{abstract}

Keywords: Foraminifera, New Replacement Name, Taxonomy, ICZN, Lower Cretaceous

\section{INTRODUCTION}

In 1989 Calvez described a new genus belonging to the Orbitolinidae as Aragonella marginata n. gen., n. sp. from the Albian of the Spanish Pyrenean Mountains ("Calcaires Urgo-Albien moyen"). The generic name referred to the nearby Spanish Province of Aragon, and the specific name to the marginal zone of the orbitolinid taxon. Because the genus was described after the publication of the monograph by Loeblich \& Tappan (1987), it has logically not been treated in it. Aragonella has neither been included in later taxonomic compilations (e.g., Kaminski, 2010, 2014; Iba et al., 2011; Mikhalevich, 2013; BouDagher-Fadel, 2018) nor mentioned in the recent redefinition of the orbitolinid genera by Cruz-Abad (2018). According to my knowledge, Aragonella marginata has not been recorded elsewhere in the literature since its description in the late 1980's. In the World Foraminifera Database (Hayward et al., 2018), it is mentioned as a "junior homonym of Hantkenina (Aragonella) Thalmann, 1942". In accordance with Article 52.1 (Principle of homonymy), and Article 60.3 (Junior homonyms without synonyms) of the International Code of Zoological Nomenclature (ICZN), the new replacement name Calvezella is introduced for Aragonella Calvez, 1989. In addition to this nomenclatural revision, a new find from the Albian of Cantabria, Northern Spain is provided (Fig. $1)$.

\section{SYSTEMATICS}

Phylum Foraminifera d'Orbigny, 1826

Class Globothalamea Pawlowski et al., 2013

Order Loftusiida Kaminski and Mikhalevich, 2004

Suborder Loftusiina Kaminski and Mikhalevich, 2004

Superfamily Orbitolinoidea Martin, 1890

Family Orbitolinidae Martin, 1890

Subfamily Dictyoconinae Moullade, 1965

Genus Calvezella Schlagintweit, nomen novum pro Aragonella Calvez, 1989

Type-species Aragonella marginata Calvez, 1989

Etymology: Named in honour of Hervé Calvez, who first described the genus. The genus name is feminine.
Remarks: The detailed description provided by Calvez (1989) is considered as still valid. Also the comparisons with the taxa Heterocoskinolina Saint-Marc, 1978, and Abrardia Neumann \& Damotte, 1960 are justified. Calvez (1989, p. 520) considered Paracoskinolina pertenuis Foury, 1968 from the Barremian of France a possible representative of "Aragonella" lacking rafters in the marginal zone and therefore being more primitive than "A." marginata (with rafters). This species has correctly been removed from Paracoskinolina and taxonomically revised as Eopalorbitolina pertenuis (Foury) by Cherchi \& Schroeder (2002).

Occurrences: The type-locality chosen by Calvez (1989) is the hermitage of Las Aras, Province of Aragon (Fig. 1a-b). In the outcropping Urgonian limestones (UrgoAlbien), Calvezella marginata is associated with other orbitolinids such as Simplorbitolina conulus Schroeder and $S$. manasi Ciry \& Rat. This assemblage characterizes the uppermost early to middle Albian (Schroeder and Neumann, 1985).

Apart from the original description, Calvezella marginata has been observed in wackestones associated with $S$. conulus from the Ramales Formation of the Solorzano section in Cantabria, south-east of the city of Santander (Schlagintweit et al., 2017, Figs. 1, 3), (Fig. 1c-d).

\section{ACKNOWLEDGEMENTS}

Many thanks to Idoia Rosales (Madrid) enabling the restudy of thin-section material of Ramirez del Pozo during a short stay at Tres Cantos (IGME). The paper benefitted from the careful reviews of François Le Coze (SaintEtienne) and Mike Kaminski (Dharan).

\section{REFERENCES}

BouDagher-Fadel, M., 2008. Evolution and geological significance of larger benthic Foraminifera. UCL Press, Second Edition): 1-693. 


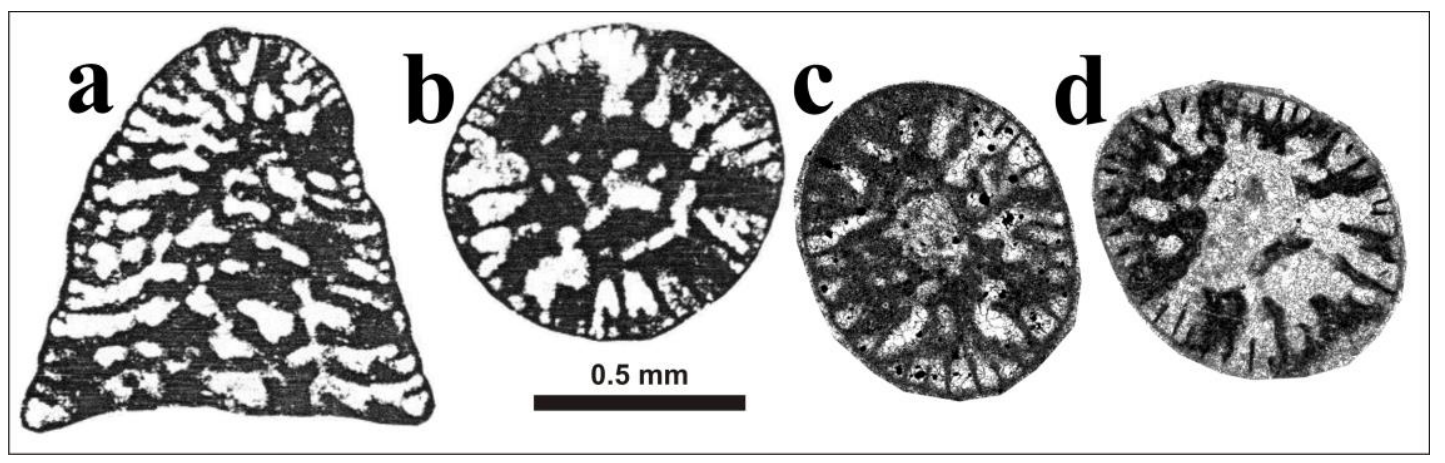

Fig. 1 Calvezella marginata (Calvez) n. comb., from the Albian of the Spanish Pyrenees (a-b), and Cantabria (c-d). a Axial section of the holotype (from Calvez, 1989, fig 2n). b Transverse section (from Calvez, 1989, fig. 2e). c-d) Slightly oblique transverse sections.

Calvez, H., 1989. Aragonella marginata n. gen., n. sp., nouvel Orbitolinidé (Foraminifère) de l'Albien des Pyrénées franco-espagnoles. Comptes rendus de l'Académie des Sciences, 308 (sér. II): 515-520.

Cherchi, A., Schroeder, R., 2002. Hallazgo de Paracoskinolina pertenuis Foury

(Orbitolinidae) en el Barremiense inferior del Pirineo catalán: reflexiones sobre su posición sistemática y filogenética. Treballs del Museu de Geologia de Barcelona, 11: 97103.

Cruz-Abad, E., 2018. Textura y Arquitectura de los Orbitolinoideos (Superfamilia Orbitolinoidea): Revisión y Caracterización. PhD Thesis University of Barcelona, 154 p. Online: https://www. tesisenred.net/ handle/10803/665998\#page $=1$

Foury, G., 1968. Le Crétacé inférieur des Alpilles. Contribution à l'étude stratigraphique et micropaléontologique. Geobios 1(1): 119-163.

Hayward, B.W., Le Coze, F., Gross, O., 2018. World Foraminifera Database. http://www.marinespecies. org/foraminifera/ on 2019-10-19.doi.10.1014284/305

Iba, Y., Sano, I., Miura, T., 2011. Orbitolinid foraminifers in the Northwest Pacific: Their taxonomy and stratigraphy. Micropaleontology, 57(2): 163-171.

Kaminski, M.A., 2004. The year 2000 classification of the agglutinated foraminifera. In: Bubik, M., Kaminski, M.A. (Eds.), Proceeding of the $6^{\text {th }}$ international workshop on agglutinated foraminifera.
Grzybowski Foundation Special Publication, 8: 237255.

Kaminski, M.A., 2014. The year 2010 classification of the agglutinated Foraminifera. Micropaleontology, 60(1): 89-108.

Loeblich, A.R., Jr., Tappan, H., 1987. Foraminiferal genera and their classification, Van Nostrand Reinhold, New York, 2 vol., 970 p., 847 pls.

Mikhalevich, V.I., 2013. New insights into the systematics and evolution of the foraminifera. Micropaleontology, 59(6): 493-527.

Neumann, M., Damotte, R., 1960. Abrardia, nouveaux genre du Crétacé Supérieur d'Aquitaine. Revue de Micropaléontologie, 3: 60-64

Saint-Marc, P., 1978. Heterocoskinolina ruskei n. gen., n. sp., Orbitolinidé nouveau du Cénomanien du Proche-Orient. Remarques sous la sous-famille des Dictoyconinae. Archives des Sciences, 31(1): 51-56.

Schlagintweit, F., Rosales, I., Najarro, M., 2017. An interesting orbitolinid assemblage from the early Albian of Cantabria (N Spain). Journal of Iberian Geology, 43 (1): 61-73.

Schroeder, R., Neumann, M., 1985 (coords.). Les grands Foraminifères du Crétacé Moyen de la région Méditerranénne. Geobios, Mémoire Spécial, 7: 1-160.

Thalmann, H.E., 1942. Foraminiferal genus Hantkenina and its subgenera. American Journal of Science, 240(11): 809-820. 